\title{
Health Policy Issue Brief: COVID-19 in Mexico, an imperative to test, trace, and isolate.
}

Daniel Bernal-Serrano ${ }^{1,2, *}$, Héctor Carrasco ${ }^{3}$, Lindsay Palazuelos ${ }^{4}$, Joel M. Mubiligi ${ }^{5,6}$, Catherine Oswald ${ }^{4}$, Joia S. Mukherjee $^{4,7}$

1. Partners In Health/Compañeros en Salud México. Mexico City, Mexico.

2. Instituto Tecnológico y de Estudios Superiores de Monterrey, Escuela de Medicina y Ciencias de la Salud, Campus Ciudad de México. Mexico City, Mexico.

3. Instituto Tecnológico y de Estudios Superiores de Monterrey, Escuela de Medicina y Ciencias de la Salud, Campus Monterrey. Monterrey, Mexico.

4. Partners In Health. Boston, United States of America.

5. Partners In Health/Inshuti Mu Buzima. Rwikinwavu, Rwanda.

6. University of Global Health Equity. Kigali, Rwanda.

7. Department of Global Health and Social Medicine, Harvard Medical School. Boston, United States of America

*Corresponding author: dbernal@pih.org, danielbernalserrano@gmail.com

\author{
Authors ORCID information \\ Daniel Bernal-Serrano: https://orcid.org/0000-0003-0608-9977 \\ Hector Carrasco: https://orcid.org/0000-0001-5657-5821 \\ Lindsay Palazuelos: https://orcid.org/0000-0002-0670-5648 \\ Joel M. Mubiligi: https://orcid.org/0000-0002-6001-192X \\ Catherine Oswald: https://orcid.org/0000-0002-3193-731X \\ Joia S. Mukherjee: https://orcid.org/0000-0003-4931-4804
}

Keywords: Policy Brief, test, tracing, isolation, quarantine, COVID-19, Mexico

\section{Abstract}

The Mexican government's approach to COVID-19 is failing. The strategy - to care for those that require hospitalization ( $20 \%$ of all cases), deliver mass communication messages, and regulate social distancing following a stoplight system for the rest of the population- is not aggressive enough for prevention. An anemic public health approach with scarce testing and no contact tracing or quarantine, has led to a sky-rocketing number of new infections and deaths. If the current trend continues, Mexico will see around 130 thousand deaths by December and a 53\% annualized rate of decrease in the GDP. The government must implement a clear federal strategy to stop the spread of the virus: widespread testing, isolation of symptomatic cases; tracing, and quarantining of their contacts. This comprehensive public health strategy with targeted social support to protect the vulnerable is a proven approach. Through evaluating other countries' programs and extrapolating lessons for the Mexican context, we demonstrate that implementing testing and contact tracing for all acute respiratory infections is feasible with Mexico's current resources. A strategy where symptomatic patients are tested and isolated and contacts are quarantined, can suppress community spread, save lives, reduce suffering, decrease the burden on hospitals, and restart the economic activity earlier and in a safer way. The more we wait to implement comprehensive testing and tracing to suppress the epidemic, the more people will become infected, and the impact of this measures will decrease. 


\section{Problem definition}

The government of Mexico's approach to COVID-19 is failing. The strategy-to care for the $20 \%$ of those who are sick and deliver mass communication messages and social distancing following a stoplight system for the rest of the population is not an aggressive enough prevention strategy. The failure of this approach is unfolding as the number of daily deaths increase, and the projections indicate that more than 130 thousand people are expected to die by early December 2020.(1) With 800 thousand deaths globally, 23 million confirmed cases,(2) and an economic downturn unseen since the Great Depression, still, the worst is yet to come. Like an acid test used to examine the purity of gold, COVID-19 has tested the social contracts and health systems of modern societies throughout the world. Some nations have been able to limit mortality and prevent economic downfall-at least for the present and foreseeable future- by employing a strong infectious disease outbreak containment strategy and social support of the vulnerable.

Mexico, an upper-middle-income country, is the 15th largest economy in the world and the second in Latin America, but the response to the pandemic has been insufficient. On the treatment side, the government has worked to increase health system capacity to provide healthcare services, but only about $20 \%$ of those with COVID need medical care.(3) The government is also tracking the epidemic via epidemiological surveillance of $10 \%$ mild cases and all severe cases that fulfil the operational case definition.(4) Yet, the government has only deployed three public health measures:

- Social distancing, with a non-enforced nationwide shelter-in-place.

- Mass communications campaign to promote hygiene measures.

- Increase hospitals' capacity to deliver healthcare services to COVID-19 patients.

These measures aim to reduce the burden of new cases or "flatten the curve" to allow hospitals to cope with severe cases. Yet, these mitigation measures have proven to be insufficient in the response to COVID-19. None of the other major pillars of public health, those that are specifically focused on disease control rather than general messages are being deployed as means to control the epidemic. These specific strategies are: widespread testing, isolation of the sick, and tracing contacts to either test them or to leave them in quarantine

\section{KEY TAKEAWAYS}

- 130,000 deaths are expected by early December in Mexico. To avoid this, we must add tried and tested public health measures to the current strategy to stop transmission of COVID-19 in Mexico.

- A suppression approach, with testing and isolation of symptomatic cases, tracing and quarantine of their contacts, as well as targeted social support, are all proven measures to save lives and enable safe economic reopening after commensurate lockdowns, as shown in Vietnam, Rwanda, China, South Korea and the state of Massachusetts in the U.S.

- The prime objective of testing in COVID-19 is to break the chain of transmission by isolating those who are infected before they can spread the infection to others and testing their contacts.

- The cost of the suppression approach would have been 2.3 billion pesos in June, which represents $14 \%$ of what the government spent in March for its COVID-19 response.

- The more we wait to implement comprehensive testing and contact tracing, the more people will become infected which limits the ability for these measures to halt the growing economic and social burden. There is no time to lose. 
with follow-up. To date, 60 thousand Mexicans have died, there are around 5 thousand new cases every day, test positivity rate is $50 \%$, and $47 \%$ of hospital beds are occupied.(5) The economic impact of COVID on Mexico has been profound with the loss of more than 20 million jobs, a $22 \%$ decline in economic activity, with an annualized decrease of $53 \%$ in the Gross Domestic Product.(6)(7)Any of these measures, whether social distancing, quarantine or isolation are economically regressive and impact the poor disproportionately. The national shelter-in-place rule alone is not sustainable in a context where half of the population subsists below the poverty line. Currently, one in five Mexicans cannot afford enough food, and insufficient public social support has made this period deleterious to the economic and social welfare of the population. Any serious public health strategy must be paired with targeted social support to the vulnerable.

\section{Relevant evidence about potential solutions}

COVID-19 does not spread in a vacuum; context matters. Every country has responded according to their perceived public policy options, governance structures, health system resources, and experiences with similar circumstances. Each country's response may be assessed with three main indicators: the number of deaths, economic impact, and adequate availability of health services.

Based on these outcomes, China, Vietnam, Germany, South Korea, Rwanda, and Costa Rica are good examples to follow due to their low number of deaths relative to their population, and modest economic decline due to the pandemic (see appendix 1 for the literature review). These countries' public health responses have eight key measures:

1. Social distancing.

2. Use of masks in public places.

3. Testing suspect cases.

4. Contact tracing and testing them when possible.

5. Isolation positive cases.

6. Quarantine of contacts pending their test.

7. Treatment for all severe cases.

\section{Definitions}

Containment approach: avoidance of community transmission through rapid identification of laboratory-confirmed cases and their isolation and management either in a medical facility or at home. Centralized isolation/quarantine: segregation of confirmed or suspect cases, or contacts of cases, outside of their households in government units during their infectious or latent period, respectively.

Close contact: Anyone who has been in contact within 2 meters of a person for more than 15 minutes with a person documented to have COVID-19 during the time the person with COVID-19 was symptomatic or two days before symptoms began.

Mitigation approach: uniform reduction in the rate at which individuals contact one another, short of complete suppression, slowing but not interrupting transmission. Suppression approach: wide-scale intensive social distancing with the aim to rapidly suppress transmission and minimize near-term cases and deaths.

Suspect case: A) A patient with acute respiratory illness (fever and at least one sign/symptom of respiratory disease, e.g., cough, shortness of breath), AND a history of travel to or residence in a location reporting community transmission of COVID-19 disease during the 14 days prior to symptom onset; OR B) A patient with any acute respiratory illness AND having been in contact with a confirmed or probable COVID-19 case (see definition of contact) in the last 14 days prior to symptom onset; OR C) A patient with severe acute respiratory illness (fever and at least one sign/symptom of respiratory disease, e.g., cough, shortness of breath; AND requiring hospitalization) AND in the absence of an alternative diagnosis that fully explains the clinical presentation. 


\section{Border control checks.}

Germany,(8) and some states in the U.S. such as New York,(1)(9) and Massachusetts,(1)(10) have shown that implementing elements two, three, four, five, and six even in the context of extensive community transmission, are promising strategies that can suppress the transmission and help to safely reopen economic, social, and cultural activities. While countries like Rwanda,(11) China,(12) Vietnam(13) and South Korea(14) added social support (in the form of food and housing) to those in quarantine or isolation. As of July 25th, China, with a population 11 times larger than Mexico, has only reported 4,653 deaths, while Germany has reported 9,200.(15) These countries have reopened most of their economic activities.(16-18)

\section{Policy alternatives}

There are three broad public health approaches to limit the effect of an epidemic: containment, suppression, or mitigation.(19-21) Policies in response to Covid-19 have varied between countries, however, many have implemented a mixture of these approaches. Mexico has chiefly adopted a plan closer to that of mitigation, while the most robust strategies have strived for suppression and/or containment. Containment aims to halt the transmission and spread of the virus before community transmission is stablished through early and strict social distancing, coupled with active case finding for isolation of the sick and quarantine of their contacts; this is socially disruptive but reduces the number of new cases. Suppression aims for the same results, by decreasing or stopping community transmission through active case detection and testing of close contacts, and it is used where containment is not possible due to social, political or economic reasons.(10)(19)Finally, mitigation aims to slow down the epidemic by detecting severe cases with limited contact tracing and reducing health care demand. In the short term, mitigation has temporary socio-economic benefits; however, in the long term, it has a high risk of increased cases, mortality,(22) and economic damage(18)(23)(24) with a somber outlook if immunity is unattainable.(11)(25) Deciding what approach to follow depends mainly on three things: the transmissibility and fatality of the pathogen; the stage of the epidemic; and the available capacity and resources to fight it.

The transmissibility and fatality of a pathogen can make strategies that work on one disease suboptimal for another. For example, compared to influenza, COVID-19 is 10-60 times more lethal, each case infects twice as many people, and it takes twice as long for the infected contacts to develop symptoms.(24) However, infected people can spread the virus days before they develop the illness (pre-symptomatic spread), and even if they remain asymptomatic. This is why, while a mitigation strategy may be effective for influenza, it is unlikely to be the most robust option against COVID-19. In the next section, we compare three public health approaches, according to the stage of the epidemic in the country, evidence from other countries, and available resources. The three approaches are summarized in Table 1. 
Table 1. Approach characteristics

\begin{tabular}{|c|c|c|c|c|}
\hline & $\begin{array}{l}\text { Components and } \\
\text { evidence }\end{array}$ & (1) Mitigation & (2) Suppression & (3) Most Proactive \\
\hline \multirow[t]{2}{*}{$\begin{array}{l}\text { Country } \\
\text { Profiles }\end{array}$} & $\begin{array}{l}\text { Examples of locations } \\
\text { where the policy has } \\
\text { been implemented }\end{array}$ & $\begin{array}{l}\text { Currently: USA } \\
\text { and Mexico. Initially: } \\
\text { UK, Italy, and Spain. }\end{array}$ & $\begin{array}{l}\text { Vietnam, China, } \\
\text { South Korea, and } \\
\text { Rwanda. }\end{array}$ & $\begin{array}{l}\text { Iceland, } \\
\text { Luxembourg, } \\
\text { Estonia, and } \\
\text { Uruguay. }\end{array}$ \\
\hline & $\begin{array}{l}\text { Average cumulative } \\
\text { COVID-19 deaths, } 76 \\
\text { days after reaching } 0.1 \\
\text { per million deaths }\end{array}$ & $\begin{array}{l}127 \text { per million(5) } \\
\text { (419 per million in } \\
\text { Mexico)(5) }\end{array}$ & $\begin{array}{ll}1.93 & \text { per } \\
\text { million(26) } & \end{array}$ & $\begin{array}{ll}65.92 & \text { per } \\
\text { million(26) } & \end{array}$ \\
\hline \multirow[t]{10}{*}{ Interventions } & Social Distancing & $x$ & $x$ & $x$ \\
\hline & $\begin{array}{l}\text { Testing: severe suspect } \\
\text { cases according to the } \\
\text { MoH definition }\end{array}$ & $x$ & $x$ & $x$ \\
\hline & $\begin{array}{l}\text { Testing: all suspect } \\
\text { cases } \\
\text { operational definition) }\end{array}$ & & $x$ & $x$ \\
\hline & $\begin{array}{ll}\text { Contact } & \text { symptom } \\
\text { surveillance } & \\
\end{array}$ & $x$ & $x$ & $x$ \\
\hline & Contact quarantine & & $\mathrm{X}$ & $\mathrm{X}$ \\
\hline & Targeted social support & & $\mathrm{x}$ & $\mathrm{X}$ \\
\hline & $\begin{array}{l}\text { Screening most high- } \\
\text { risk populations }\end{array}$ & & $x$ & $x$ \\
\hline & Testing all contacts & & & $x$ \\
\hline & Isolation of the infected & & $x$ & $x$ \\
\hline & Validation level* & Applicable & Impact & Empirical \\
\hline Evidence & Results & 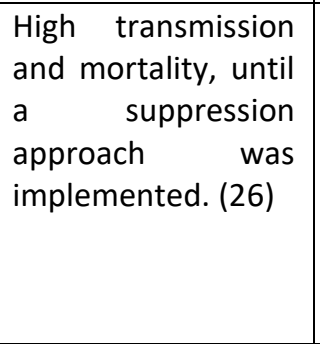 & \begin{tabular}{l}
\multicolumn{3}{l}{ Suppression } \\
and/or control of \\
the epidemic. Low \\
numbers \\
deaths, a safe \\
restart \\
economic \\
activities.(26)
\end{tabular} & $\begin{array}{l}\text { Suppression of the } \\
\text { pandemic in Iceland } \\
\text { and Uruguay; } \\
\text { containment in } \\
\text { Luxembourg and } \\
\text { Estonia.(26) }\end{array}$ \\
\hline \multicolumn{5}{|c|}{$\begin{array}{l}\text { *Validation level: quality of evidence within the developed the Theoretical, Empirical, Applicable, and Replicable Impact } \\
\text { rating system (THEARI). This five-tier system ranges from one (theory only) to five (impact validated) full stars. Its } \\
\text { purpose is to provide guidance for scientists and policymakers to classify what qualifies as evidence and potential } \\
\text { appropriateness for application.(27) }\end{array}$} \\
\hline
\end{tabular}




\subsection{Current mitigation approach: social distancing, sentinel surveillance and limited contact tracing}

Mexico has opted for a mitigation strategy that aims to lower and delay the epidemic while limiting a surge of health care use given the external shock in the demand for health care. The Jornada Nacional de Sana Distancia (National Healthy Distance campaign) began on March 24th and it has been accompanied by centralized testing in hospitals and clinics for severe cases plus $10 \%$ of the symptomatic cases.(4) Additionally, this approach includes scaled up health system capacity to deliver care to severe cases by converting more than 600 hospitals(28) to treat only Covid-19 cases, acquiring ventilators abroad, and hiring more health professionals. Currently, the transition towards the New Normality campaign consists of reopening economic, social, and cultural sectors in phases, according to relevant epidemiological and social indicators. Countries that reopened without proper control of the epidemic such as the UK, US, Italy, and Spain,(24) have suffered a high number of deaths, with insufficient immunity in the general population to avoid another wave of the outbreak.(29)

\subsection{Suppression approach: Symptomatic testing, contact tracing, isolation/quarantine, and targeted social support}

The proven strategy to suppress the COVID-19 epidemic is actively finding infectious cases and cutting chains of transmission by means of case isolation and quarantining close contacts. Doing so will require investment, but it will be less expensive than the $7-10 \%$ expected decline in the GDP due to the current lockdown.(30) From an economic perspective, Mexico will not be able to reopen non-essential businesses until the number of infections and deaths diminish, which depends on lockdowns. From the epidemiological perspective, population immunity through a mitigation approach expects nearly 17 million hospitalizations and 1 million deaths.(31) Additionally, duration of immunity against SARS-CoV-2 is currently unknown. To avoid this societal burden, testing of all symptomatic cases, contact tracing, and isolations/quarantines have proven value at decreasing (by $64 \%$ in an LSHTM model)(32) or stopping community transmission (see appendix 1).

\subsubsection{The why}

Contact tracing is the process of identifying, assessing, and managing individuals who have been in close contact with an infected person,(33) and, according to the PAHO "health authorities have the ethical obligation to conduct rigorous contact tracing and to act without delay based on the information obtained".(34) The example of Vietnam is illustrative. Despite being one of the first countries affected by COVID-19, it has been able to quickly and effectively implement a robust strategy, including contact tracing.(35) Through intensive contact tracing, Vietnam has cut chains of transmission and control surging disease clusters. Similarly, immediately after its first case, Rwanda conducted systematic testing and contact tracing, in a massive human rights effort to curtail the spread of disease.(11) Hence, testing of symptomatic cases and contact tracing protocols are useful to safely re-open social and economic activity, and control the spread of COVID-19. Additionally, testing has therapeutic purposes, such as instituting the use of remdesivir(36) or steroids,(37) treatments that may save the lives of people with COIVD-19 but be futile or even harmful in other respiratory illnesses, such as influenza, whose season is coming.(38) Overall, the primary purpose of testing is to control the COVID-19 epidemic by cutting the chains of transmission, beyond epidemiological surveillance alone. This is why testing by itself is a sub-optimal use of money, but coupling it with case isolation and contact quarantine has demonstrated tangible impact in the states of Massachusetts and New York in the U.S.,(1) South Korea,(39) Vietnam,(35)(40)(41)China,(24) and Rwanda.(11) 


\subsubsection{The how}

This alternative further builds on the current approach by the Mexican government with testing using molecular methods for all individuals that fulfill the World Health Organization suspect case; contact tracing; isolation/quarantine; and targeted social support. Strong evidence (see Appendix 1) supports testing $100 \%$ of symptomatic cases, and their close contacts and isolate or quarantine them, respectively.(42) Quarantine is recommended for those who are asymptomatic and are close contacts of a confirmed COVID-19 case,(34) (41) and isolation is recommended for those who are positive for COVID-19 or contacts of primary cases that develop symptoms.(39)(43)(44) Isolation and quarantine have been especially successful when individuals are offered a centralized isolation/quarantine space, out of their households, such as hotels, and temporary shelters or hospitals.(12)(35)(45) COVID-19 spreads quickly and individuals are contagious before or even without having symptoms; hence, effective contact tracing of infected individuals mandates prompt app-based methods, phone calls, or home visits for immediate contact notification and quarantine.(46) In our context, low-income workers who rely on daily labor are incentivized to sidestep testing if a positive result means forced restrictions that threaten their livelihood. To prevent this, positive cases, close contacts, and their families will require targeted social support including food packages and cash transfers to alleviate the economic burden. Since this is an intersectoral responsibility and to avoid over assumptions, we did not include the costs of social support programs for the purpose of the ensuing exercises.

\subsubsection{The monthly cost of test \& tracing: the case of June 2020}

Mexico had enough resources to meet the demand of tests and contact tracers to implement this policy option in June 2020. Nearly 1.64 million tests would have been required in June 2020 (see Appendix 6 to see the methods), in addition to 32,197 people to contact trace by phone and field outreach for rural communities without phone or internet coverage (See Appendix 3 to see the methods used to calculate these numbers). The staffing costs would be 160 million pesos. For the month of June 2020, testing all respiratory infections and tracing contacts would have cost an estimated 2.3 billion pesos, which represents around $14 \%$ of actual Mexican government spending due to the COVID-19 crisis during March 2020 (see a costing exercise in Appendix 5).

These costs could decrease substantially. Mexico has more than 250,000 Promotores de Salud and 600,000 scholars affiliated with the program Jovenes Construyendo el Futuro, who can be trained as contact tracers. Additionally, medical students (around 133,000)(47) could be recruited on a voluntary basis, an approach that has worked in areas of the US. The monthly cost of the workforce would be approximately 10 million pesos in logistics expenses if Mexico repurposes Jovenes Construyendo el Futuro, Promotores de Salud, or requests volunteer medical students. On the testing side, the cost of each PCR test, including sampling and analysis, at the lowest cost private laboratory is $\$ 1,300.00 \mathrm{MXN},(48-50)$ but economies of scale plus pooled testing might reduce the cost of testing to a tenth of this.(49-51) Therefore, testing in June 2020 could have cost as little as $\mathbf{2 1 3}$ million pesos; however, for our cost exercise, we will assume that economies of scale and pooled testing were unattainable. We are limited in making impact forecasts because the true burden of disease is unknown and the effect of this intervention in Mexico, though promising, has not been tested. The test and tracing policy in Mexico City(52) may yield valuable data and lessons to expand this program to the rest of the country.

\subsection{Most proactive approach: Comprehensive testing, contact tracing, isolate/quarantine, targeted social support}

It is estimated that half of the COVID-19 cases around the world have been acquired through contact with asymptomatic people.(53) Testing and isolating/quarantining only symptomatic cases and their contacts, as recommended in alternative two, may not be enough to curtail the pandemic. Hence, this alternative adds comprehensive testing to the elements already discussed in alternative two. Mexico has followed a centralized and symptoms-based testing system. Comprehensive testing implies decentralizing it from hospitals and clinics, 
and expanding it to drive-throughs, relevant institutions, and community-based walk-ins. This strategy makes testing more accessible and timely, capturing asymptomatic and pre-symptomatic cases, as recommended by the World Health Organizations to countries who can afford it.(33) This alternative also actively tests potential super spreaders, people who by their societal role have a higher probability to transmit the disease to others if they become sick, such as health care workers,(54) people living in high-risk closed settings (dormitories, institutions, prisons, long-term-care homes), and people working in highly crowded places (markets, stores, restaurants, schools, and factories). Countries such as Iceland,(55)(56)Luxembourg,(57) Estonia,(58) New Zealand,(59) Uruguay,(60) tried this approach which helped them to reduce community transmission.

For this alternative, we used data from the Institute for Health Metrics and Evaluation (IHME), to determine the number of estimated Covid-19 infections in Mexico.(1) From June 1st, to June 31st, the estimated number was 4,092,040 (95\% Confidence Interval, 3,906,092 -- 4,526,087). The positivity rate varies according to the extent of the community transmission. Using as a reference the WHO and China joint commission report,(61) and information from some states in the U.S., pursuing testing of all symptomatic cases in the general population during ongoing community transmission(62) conveys an expected positivity rate of around $10-15 \%$. Hence, a total of $30,690,300$ tests (or 990,009 daily) would be required in June to capture $75 \%$ of the Covid-19 cases. This is the minimum percentage of people with positive tests that must be isolated to reduce the R0 number to below 1.(32) For this alternative to be successful, it will be crucial to target contacts of positive cases(33) and potential super spreaders, especially health workers providing care to Covid-19 patients, people and staff in prisons, and staff working in nursing homes, who are recommended to be tested on a weekly basis.(54)(63)(64)

Based on the projections by IHME and considering the same costs per unit and patients to staff ratio this alternative would have increased the number of tests and contact tracers by a factor of 18 compared to alternative two, and would have required making almost 990,009 tests daily and an army of 648,360 testers and contact tracers in June. The cost to implement this alternative would have been $\$ 43,079$ million pesos, which represents $261 \%$ of what the Mexican government spent due to the COVID-19 crisis in Health during March 2020. See Appendices 4 and 5 for more details on cost and staffing needs.

\subsection{Projecting the outcomes}

We considered five criteria to contrast the three alternatives. For a fair comparison, we also used a weighting system to prioritize the value of these criteria from $0-100 \%$ according to our perception of key concerns by the current administration and the Mexican people. For example, we gave the highest weight value to deaths prevented and the lowest to implementation burden. The system to prioritize is explained further in Appendix 2. For each criterion, the full score was given when a greater effect was expected, while $2 / 3$ or $1 / 3$ of the score was assigned for a moderate or limited effect, respectively. Then, the value in each criterion was added to obtain a final score, the maximum total score being $100 \%$, which would mean an optimal response.

- Deaths prevented: Compare the policy alternatives with the current approach in terms of Covid-19 related and indirect deaths prevented by implementing that approach.

- Amount and quality of evidence supporting the set of measures: Consider the number and quality of published academic papers relative to the current approach.

- Averted negative economic impact: Captures the overall negative economic impact expected by pursuing each alternative. This considers the economic impact of constant lockdowns when cases arise in an area and the costs from premature deaths.

- Low economic investment: Considers the total resources invested in launching a system that integrates all that the policy alternative entails.

- Low implementation burden: Includes the additional staff needed to implement the policy alternative. 
Table 2. Comparison of Projected Policy Impact

\begin{tabular}{|l|c|c|c|}
\hline Approach & $\begin{array}{l}\text { 1. Mitigation (current) } \\
(4)(65-67)\end{array}$ & $\begin{array}{l}\text { 2. Suppression } \\
(32)(42)(44)(33)(68)\end{array}$ & $\begin{array}{l}\text { 3. Most proactive (42) } \\
(54)(69)(70)\end{array}$ \\
\hline Deaths prevented (30\%) & + & ++ & ++ \\
\hline $\begin{array}{l}\text { Amount and quality of } \\
\text { evidence supporting this set } \\
\text { of measures (30\%) }\end{array}$ & + & +++ & ++ \\
\hline $\begin{array}{l}\text { Averted negative economic } \\
\text { impact of the pandemic (20\%) }\end{array}$ & + & ++ & + \\
\hline $\begin{array}{l}\text { Low economic investment } \\
\text { (10\%) }\end{array}$ & +++ & ++ & + \\
\hline $\begin{array}{l}\text { Low implementation burden } \\
\text { (20\%) }\end{array}$ & +++ & ++ & $70 \%$ \\
\hline \multicolumn{1}{|c|}{ Total Score } & $47 \%$ & $83 \%$ & + \\
\hline
\end{tabular}

+ limited effect, ++ moderate effect, +++ greater effect

\subsubsection{Confront the trade-offs}

In terms of economic investment, the current approach, which involves stay-at-home recommendations when cases arise, is the least costly. Alternative two would have cost around 2.3 billion pesos in June, while alternative three would have cost fifteen times that amount.

According to evidence from other countries that did not implement a public health response including widespread testing and contact tracing, the current approach would result in the most deaths, while alternatives two and three have averted deaths. For example, in the state of Massachusetts, where testing and contact tracing was initiated in a setting of high community transmission, the number of confirmed daily infections has decreased from 5,131 to 350, and the number of daily deaths from 176 to 21, from late April to July 25th.(1)

In Mexico, implementing alternative two or three in June would have implied increasing testing by a factor of 6 and 105, respectively, and starting a nation-wide program of contact tracing. In addition, it would also require social support programs to confirm that isolations and quarantines can be followed by vulnerable populations. The current strategy's lower implementation burden and economic investment are likely to be offset by the economic toll of having regular lockdowns when cases start to rise, which for the current lockdown is projected to be around 7\% of the GDP. (30)

In relation to the current mitigation approach, no country has curtailed the pandemic relying on epidemic surveillance to trigger localized lockdowns without using testing and contact tracing, and isolation/quarantine. However, there is a clear difference in values between alternative one, focused on the cautious use of resources, and alternative three, which is the most cautious with lives. Symptomatic testing and contact tracing to isolate confirmed cases and quarantine their contacts were implemented in Singapore, Taiwan, South Korea, Cuba, and other countries resulting in good outcomes. We must recognize that individual autonomy was clearly curtailed in these settings, while isolation and quarantine are voluntary in Mexico. Testing suspected cases, their contacts, and high-risk individuals even when they were asymptomatic was implemented in some countries such as Iceland, Luxembourg, and Estonia, and some Low-and-Middle income countries such as Uruguay and Cuba to suppress community transmission. However, there is not enough evidence of using this approach in the context of already widespread transmission. Due to its high cost, this approach might be better suited once the amount of symptomatic cases is low enough. However, there are still some benefits in testing asymptomatic cases in key 
societal roles such as healthcare workers, caregivers in nursing homes, and staff working in prisons. As supported in Appendix 1, there is robust evidence supporting alternative two, but little supporting alternative one or three.

\section{Policy recommendation}

We strongly recommend the suppression approach. This alternative builds on the current strategy with three additional elements: testing of all suspect cases, contact tracing by phone or door-to-door in rural communities, and isolation of cases with quarantine of their contacts. The suppression approach enables a decrease in infections and deaths, which is a necessary and achievable step for Mexico to reopen safely. Implementing this endeavor would have required an approximate investment of 2.3 billion pesos in June, and its expected effectiveness would require less resources in the months thereafter, reestablishing economic activity while avoiding thousands of deaths. If private laboratories are required to fulfill the demand, the price of the test should be set by the government to promote efficiency at a marginal cost of production. Once the pandemic is suppressed, this infrastructure can be used for containment through routine screening of high-risk populations, such as restaurant workers, retail vendors, healthcare workers, teachers, or bus drivers. The implementation will be burdensome and requires careful consideration of the social support required for people in isolation and quarantine. However, there is enough national and international expertise to build a contact tracing program that successfully controls the epidemic, something that Vietnam, Rwanda, Massachusetts, China, and Cuba have done. We believe that it is an error to privilege the operational burden and direct economic costs of the response over what most of the population weighs more highly: saving lives and avoiding the negative economic impact of the pandemic on Mexican families.

\section{Conclusion}

Evidence indicates that, although the current mitigation strategy in Mexico is rated as applicable in the THEARI system,(27) no country has managed to control the disease relying on epidemic surveillance to trigger lockdowns; additionally, the authors found no literature that supports the current policy of symptom surveillance for contacts -without quarantine- to limit the spread of the disease. The national lock-down gave us time to structure a system that isolates positive cases and quarantines their contacts. We must keep in mind that for mitigation to be effective, it demands a continuous lockdown until population immunity is reached, but effectiveness and duration of immunity is still under study.(25)

In contrast, there is emerging evidence supporting the impact of testing suspect COVID-19 cases to isolate confirmed cases, trace and quarantine their contacts. When overlapped with a lockdown, this epidemiologically suppressive action is able to decrease the rate of infection in a shorter time span, so it is strategically used as a containment tool. Therefore, the negative economic effects of widespread and long lockdowns are curtailed. Using testing and contact tracing for suppression is certainly costlier than for containment, since in the community transmission phase there are more cases. Nevertheless, the maximum cost of implementing in June would have been 2.3 billion pesos, less than $14 \%$ of what the Mexican government spent in March(71) for the response to the COVID-19 epidemic. Suppression is likely to be more cost-effective than the mitigation strategy by limiting the number of infections, which would decrease the number of hospitalizations, as well as averting deaths.

A strategy where symptomatic patients are tested and isolated and contacts are quarantined, can suppress community spread, save lives, reduce suffering, decrease the burden on hospitals, and restart economic activity earlier and in a safer way. Every day we wait to enact this approach, more people will become infected, and its ability to limit the economic and social burden is significantly derailed.

There is no time to lose.

Conflicts of Interest: The authors declare no conflicts of interest with this work. 
CRediT author's contribution statement: Daniel Bernal-Serrano: Conceptualization, Methodology, Formal Analysis, Investigation, Writing- Original Draft. Hector Carrasco: Conceptualization, Methodology, Formal Analysis, Investigation, Writing- Original Draft, Visualization, Supervision. Lindsay Palazuelos: Validation, Writing- Review \& Editing. Joel Mubiligi: Writing - Original Draft. Cate Oswald: Writing- Review \& Editing. Joia S. Mukherjee: Writing- Review \& Editing.

Acknowledgements: This brief would have been possible without the invaluable help of our intern Patricia Fuentes who assisted our team to collect data and provided editing help, and Almudena Laris for proofreading the text.

\section{References}

1. IHME | COVID-19 Projections [Internet]. Institute for Health Metrics and Evaluation. [cited $2020 \mathrm{Jul}$ 25]. Available from: https://covid19.healthdata.org/

2. COVID-19 Map [Internet]. Johns Hopkins Coronavirus Resource Center. [cited 2020 Aug 25]. Available from: https://coronavirus.jhu.edu/map.html

3. Guan W, Ni Z, Hu Y, Liang W, Ou C, He J, et al. Clinical Characteristics of Coronavirus Disease 2019 in China. N Engl J Med. 2020 Apr 30;382(18):1708-20.

4. Secretaría de Salud. Lineamiento Estandarizado para la Vigilancia Epidemiológica y por Laboratorio de la enfermedad respiratoria viral [Internet]. 2020 [cited 2020 Jun 16]. Available from: https://www.gob.mx/salud/documentos/lineamiento-estandarizado-parala-vigilancia-epidemiologica-y-por-laboratorio-de-la-enfermedad-respiratoria-viral

5. Mexico: Coronavirus Pandemic - Our World in Data [Internet]. [cited 2020 Jul 25]. Available from: https://ourworldindata.org/coronavirus/country/mexico?country= MEX

6. Encuesta Nacional de Ocupación y Empleo (ENOE), población de 15 años y más de edad [Internet]. 2020 [cited 2020 Jun 21]. Available from: https://www.inegi.org.mx/programas/enoe/15ymas/default.html\#Tabulados

7. INEGI IN de E y. Producto Interno Bruto. PIB. Trimestral [Internet]. Cuentas de Bienes y Servicios del Sistema de Cuentas Nacionales de México. SCNM; Producto Interno Bruto. Trimestral. Instituto Nacional de Estadística y Geografía. INEGI; 2020 [cited 2020 Jun 21]. Available from: https://www.inegi.org.mx/temas/pib/

8. Reintjes R. Lessons in contact tracing from Germany. BMJ [Internet]. 2020 Jun 25 [cited 2020 Aug 25];369. Available from: https://www.bmj.com/content/369/bmj.m2522

9. N.Y.C. Hired 3,000 Workers for Contact Tracing. It's Off to a Slow Start. - The New York Times [Internet]. [cited 2020 Jul 25]. Available from: https://www.nytimes.com/2020/06/21/nyregion/nyc-contact-tracing.html

10. Sierra Leone Ebola Lessons Shaping Massachusetts COVID-19 Response | Partners In Health [Internet]. [cited 2020 Jul 25]. Available from:

https://www.pih.org/article/sierra-leone-ebola-lessons-shaping-massachusetts-covid19-response

11. Binagwaho A. We Need Compassionate Leadership Management Based on Evidence to Defeat COVID-19. Int J Health Policy Manag. 2020 May;2.

12. Pan A, Liu L, Wang C, Guo H, Hao X, Wang Q, et al. Association of Public Health Interventions With the Epidemiology of the COVID-19 Outbreak in Wuhan, China. JAMA. 2020 May 19;323(19):1915-23.

13. Quach H-L, Hoang N-A. COVID-19 in Vietnam: A lesson of pre-preparation. J Clin Virol. 2020 Jun 1;127:104379.

14. Oh J, Lee J-K, Schwarz D, Ratcliffe HL, Markuns JF, Hirschhorn LR. National Response to COVID-19 in the Republic of Korea and Lessons Learned for Other Countries. Health Syst Reform. 2020 Jan 1;6(1):e1753464.

15. Coronavirus (COVID-19) Deaths - Statistics and Research [Internet]. Our World in 
Data. [cited 2020 Aug 26]. Available from: https://ourworldindata.org/covid-deaths

16. Natives D. Covid-19 impact and responses: Vietnam [Internet]. Fair Wear. 2020 [cited 2020 Jun 20]. Available from: https://www.fairwear.org/covid-19-dossier/covid-19guidance-for-production-countries/covid-19-impact-and-responses-vietnam/

17. Bennhold K, Eddy M. Germany's Reopening Offers Hope for a Semblance of Normal Life. The New York Times [Internet]. 2020 May 6 [cited 2020 Jun 20]; Available from: https://www.nytimes.com/2020/05/06/world/europe/germany-merkel-coronavirusreopening.html

18. Johnson K. Can Europe and the U.S. Follow China's Lead on Economic Recovery? [Internet]. Foreign Policy. 2020 [cited 2020 Jun 20]. Available from: https://foreignpolicy.com/2020/03/25/europe-china-us-economic-recovery-vcoronavirus/

19. WHO. COVID-19 STRATEGY UPDATE [Internet]. Geneva, Switzerland.: World Health Organization; 2020 Apr. Available from: https://www.who.int/docs/defaultsource/coronaviruse/covid-strategy-update-14april2020.pdf?sfvrsn=29da3ba0_6

20. Walker PGT, Whittaker C, Watson OJ, Baguelin M, Winskill P, Hamlet A, et al. The impact of COVID-19 and strategies for mitigation and suppression in low- and middleincome countries. Science. 2020 Jul 24;369(6502):413-22.

21. WHO. Considerations for quarantine of individuals in the context of containment for coronavirus disease (COVID-19) [Internet]. World Health Organization. 2020 [cited 2020 Aug 16]. Available from: https://www.who.int/publications/i/item/considerationsfor-quarantine-of-individuals-in-the-context-of-containment-for-coronavirus-disease(covid-19)

22. OECD. Flattening the COVID-19 peak: Containment and mitigation policies [Internet]. OECD. 2020 [cited 2020 Jun 21]. Available from:

http://www.oecd.org/coronavirus/policy-responses/flattening-the-covid-19-peakcontainment-and-mitigation-policies-e96a4226/

23. OECD. OECD Economic Outlook, Volume 2020 Issue 1 : Preliminary version | OECD iLibrary [Internet]. 2020 [cited 2020 Jun 21]. Available from: https://www.oecdilibrary.org//sites/0d1d1e2een/1/3/2/1/index.html?itemld=/content/publication/0d1d1e2een\&_csp_=bfaa0426ac4b641531f10226ccc9a886\&itemIGO=oecd\&itemContentType=\#

24. Li Z, Chen Q, Feng L, Rodewald L, Xia Y, Yu H, et al. Active case finding with case management: the key to tackling the COVID-19 pandemic. The Lancet. 2020 Jun;S0140673620312782.

25. Long Q-X, Tang X-J, Shi Q-L, Li Q, Deng H-J, Yuan J, et al. Clinical and immunological assessment of asymptomatic SARS-CoV-2 infections. Nat Med. 2020 Jun 18;1-5.

26. Coronavirus Pandemic Data Explorer [Internet]. Our World in Data. [cited 2020 Aug 26]. Available from: https://ourworldindata.org/coronavirus-data-explorer

27. Research B and SS at N. Standards for evidence in policy decision-making [Internet]. Behavioural and Social Sciences at Nature Research. 2020 [cited 2020 Jun 22]. Available from: http://socialsciences.nature.com/users/399005-kairuggeri/posts/standards-for-evidence-in-policy-decision-making

28. Expansión política. México cuenta con 610 hospitales y 11,634 camas para atender COVID-19 [Internet]. 2020 [cited 2020 Jun 16]. Available from:

https://politica.expansion.mx/mexico/2020/04/25/salud-confirma-13-842-casos-y-1-305defunciones-por-covid-19

29. López L, Rodó X. The end of social confinement and COVID-19 re-emergence risk. Nat Hum Behav [Internet]. 2020 Jun 22 [cited 2020 Jun 30]; Available from: http://www.nature.com/articles/s41562-020-0908-8

30. CONEVAL. La crisis sanitaria generada por la COVID-19 y sus consecuencias económicas ponen en riesgo avances en desarrollo social y puede afectar en mayor medida a grupos vulnerables. [Internet]. 2020 [cited 2020 Jun 22]. Available from: https://www.coneval.org.mx/Evaluacion/IEPSM/Paginas/Politica_Social_COVID19.aspx 
31. He W, Yi GY, Zhu Y. Estimation of the basic reproduction number, average incubation time, asymptomatic infection rate, and case fatality rate for COVID-19: Meta-analysis and sensitivity analysis. medRxiv. 2020 May 5;2020.04.28.20083758.

32. Kucharski AJ, Klepac P, Conlan AJK, Kissler SM, Tang ML, Fry H, et al. Effectiveness of isolation, testing, contact tracing, and physical distancing on reducing transmission of SARS-CoV-2 in different settings: a mathematical modelling study. Lancet Infect Dis. 2020 Jun;S1473309920304576.

33. WHO. Contact tracing in the context of COVID-19: interim guidance [Internet]. World Health Organization. 2020 [cited 2020 Jun 17]. Available from: https://apps.who.int/iris/handle/10665/332049

34. PAHO. Considerations for the Implementation and Management of Contact Tracing for Coronavirus Disease 2019 (COVID-19) in the Region of the Americas [Internet]. Washington (DC): Panamerican Health Organization; 2020 Jun. Available from: https://iris.paho.org/bitstream/handle/10665.2/52384/PAHOIMSPHECOVID19200032_eng.pdf?sequence $=1$ \&isAllowed $=y$

35. Duong DM, Le VT, Ha BTT. Controlling the COVID-19 Pandemic in Vietnam: Lessons From a Limited Resource Country. Asia Pac J Public Health. 2020 May $19 ; 101053952092729$.

36. Goldman JD, Lye DCB, Hui DS, Marks KM, Bruno R, Montejano R, et al. Remdesivir for 5 or 10 Days in Patients with Severe Covid-19. N Engl J Med. 2020 May 27;NEJMoa2015301.

37. Ledford $\mathrm{H}$. Coronavirus breakthrough: dexamethasone is first drug shown to save lives. Nature. 2020 Jun 16;d41586-020-01824-5.

38. Rubin R. What Happens When COVID-19 Collides With Flu Season? JAMA [Internet]. 2020 Aug 20 [cited 2020 Aug 25]; Available from: https://jamanetwork.com/journals/jama/fullarticle/2769835

39. Enrico D. China's democratic neighbours and coronavirus. Brief Eurpean Parliam. 2020 May;8.

40. Thanh HN, Van TN, Thu HNT, Van BN, Thanh BD, Thu HPT, et al. Outbreak investigation for COVID-19 in northern Vietnam. Lancet Infect Dis. 2020 May;20(5):535-6.

41. Dreisbach JL. Vietnamese Public Health Practices in the Advent of the COVID-19 Pandemic: Lessons for Developing Countries. Asia Pac J Public Health. 2020 May $14 ; 101053952092726$.

42. Cheng H-Y, Jian S-W, Liu D-P, Ng T-C, Huang W-T, Lin H-H, et al. Contact Tracing Assessment of COVID-19 Transmission Dynamics in Taiwan and Risk at Different Exposure Periods Before and After Symptom Onset. JAMA Intern Med [Internet]. 2020 May 1 [cited 2020 Jun 17]; Available from: https://jamanetwork.com/journals/jamainternalmedicine/fullarticle/2765641

43. Xu CC Jing Dong, Kuang. Using hotel for coronavirus patients would be a massive help in fighting the pandemic [Internet]. Business Insider. [cited 2020 Jun 16]. Available from: https://www.businessinsider.com/fight-covid19-pandemic-use-hotels-coronaviruspatients-2020-4

44. Ma CG. COVID-19 Case Detection: Cuba's Active Screening Approach. MEDICC Rev. 2020 May 12;22(2):6.

45. Brauner JM, Mindermann S, Sharma M, Stephenson AB, Gavenčiak T, Johnston D, et al. The effectiveness and perceived burden of nonpharmaceutical interventions against COVID-19 transmission: a modelling study with 41 countries. medRxiv. 2020 Jun 2;2020.05.28.20116129.

46. Walensky RP, Rio $C$ del. From Mitigation to Containment of the COVID-19 Pandemic: Putting the SARS-CoV-2 Genie Back in the Bottle. JAMA. 2020 May 19;323(19):188990.

47. Secretaría de Salud. 239. Se incrementa en 43 mil el número de estudiantes de medicina en los últimos 8 años [Internet]. Gobierno de México. 2020 [cited 2020 Jun 16]. Available from: http://www.gob.mx/salud/prensa/239-se-incrementa-en-43-mil-el- 
numero-de-estudiantes-de-medicina-en-los-ultimos-8-anos

48. Salud Digna - Covid19 [Internet]. 2020 [cited 2020 Jun 17]. Available from:

https://salud-digna.org/covid-19/estudio-covid-19/

49. Wacharapluesadee S, Kaewpom T, Ampoot W, Ghai S, Khamhang W,

Worachotsueptrakun $\mathrm{K}$, et al. Evaluating the efficiency of specimen pooling for PCR-

based detection of COVID-19. J Med Virol [Internet]. [cited 2020 Jun 16];n/a(n/a).

Available from: https://onlinelibrary.wiley.com/doi/abs/10.1002/jmv.26005

50. Cherif A, Grobe N, Wang X, Kotanko P. Simulation of Pool Testing to Identify Patients With Coronavirus Disease 2019 Under Conditions of Limited Test Availability. JAMA Netw Open. 2020 Jun 23;3(6):e2013075.

51. Assessment of Specimen Pooling to Conserve SARS CoV-2 Testing Resources | American Journal of Clinical Pathology | Oxford Academic [Internet]. [cited 2020 Jun 16]. Available from: https://academic.oup.com/ajcp/article/153/6/715/5822023

52. Forbes. CDMX presenta plan de contención de Covid-19: rastrearán cadenas de contagio [Internet]. 2020 [cited 2020 Jun 17]. Available from:

https://www.forbes.com.mx/noticias-cdmx-programa-contencion-contagios-covid-19/

53. Oran DP, Topol EJ. Prevalence of Asymptomatic SARS-CoV-2 Infection. Ann Intern Med [Internet]. 2020 Jun 3 [cited 2020 Aug 26]; Available from:

https://www.acpjournals.org/doi/10.7326/M20-3012

54. Grassly N, Pons Salort M, Parker E, White P, Ainslie K, Baguelin M, et al. Report 16:

Role of testing in COVID-19 control [Internet]. London: Imperial College London; 2020

Apr [cited 2020 Jun 16]. (MRC Centre for Global Infectious Disease Analysis). Available from: http://spiral.imperial.ac.uk/handle/10044/1/78439

55. How Iceland Beat the Coronavirus | The New Yorker [Internet]. 2020 [cited 2020 Jun 21]. Available from: https://www.newyorker.com/magazine/2020/06/08/how-icelandbeat-the-coronavirus

56. Ortiz A. Iceland's 'Test Everyone' Goal Has Skeptics, but It May Be Working. The New York Times [Internet]. 2020 Apr 9 [cited 2020 Jun 21]; Available from:

https://www.nytimes.com/2020/04/09/world/europe/coronavirus-testing-iceland.html

57. Time. Luxembourg Testing Its Entire Population For Coronavirus [Internet]. Time. 2020 [cited 2020 Jun 21]. Available from: https://time.com/5844195/luxembourg-covid19testing-program/

58. BNN. Estonia looking at mass tests' option to determine latency of COVID-19 [Internet]. Baltic News Network - News from Latvia, Lithuania, Estonia. 2020 [cited 2020 Jun 21].

Available from: https://bnn-news.com/estonia-looking-at-mass-tests-option-todetermine-latency-of-covid-19-211963

59. How New Zealand beat coronavirus: testing, tracing, trust in advice - Business Insider [Internet]. [cited 2020 Jun 22]. Available from: https://www.businessinsider.com/hownew-zealand-beat-coronavirus-testing-tracing-trust-in-government-2020-5

60. Nicolás Saldías. Uruguay, the exception to Latin America's COVID-19 surge [Internet]. Global Americans. 2020 [cited 2020 Jun 22]. Available from:

https://theglobalamericans.org/2020/05/uruguay-the-exception-to-latin-americas-covid19-surge/

61. WHO. Report of the WHO-China Joint Mission on Coronavirus Disease 2019 (COVID19) [Internet]. WHO; Available from: https://www.who.int/docs/default-

source/coronaviruse/who-china-joint-mission-on-covid-19-final-report.pdf

62. Daily State-by-State Testing Trends [Internet]. Johns Hopkins Coronavirus Resource Center. [cited 2020 Jun 22]. Available from:

https://coronavirus.jhu.edu/testing/individual-states

63. CDC. Coronavirus Disease 2019 (COVID-19) [Internet]. Centers for Disease Control and Prevention. 2020 [cited 2020 Jun 20]. Available from:

https://www.cdc.gov/coronavirus/2019-ncov/hcp/nursing-homes-testing.html

64. COVID-19 Unified-Command Group to Launch Mass Testing Strategy of State's Prison Population and Staff [Internet]. 2020 [cited 2020 Jun 21]. Available from:

https://www.tn.gov/governor/news/2020/5/1/covid-19-unified-command-group-to- 
launch-mass-testing-strategy-of-state-s-prison-population-and-staff-.html

65. Flaxman S, Mishra S, Gandy A, Unwin HJT, Mellan TA, Coupland H, et al. Estimating the effects of non-pharmaceutical interventions on COVID-19 in Europe. Nature. 2020 Jun 8;1-8.

66. Mass testing won't happen in Mexico. That's the way the government wants it - CNN [Internet]. 2020 [cited 2020 Jun 17]. Available from:

https://edition.cnn.com/2020/05/15/americas/mexico-coronavirus-testing-int//index.html

67. CDC. Implementation of Mitigation Strategies for Communities with Local COVID-19

Transmission [Internet]. Centers for Disease Control and Prevention; 2020 May p. 10.

Available from: https://www.cdc.gov/coronavirus/2019-ncov/downloads/communitymitigation-strategy.pdf

68. Salath M, Althaus CL, Neher R, Stringhini S, Hodcroft E, Fellay J, et al. COVID-19 epidemic in Switzerland: on the importance of testing, contact tracing and isolation. Swiss Med Wkly [Internet]. 2020 Mar 19 [cited 2020 Jun 17]; Available from: https://doi.emh.ch/smw.2020.20225

69. Balilla J. Assessment of COVID-19 Mass Testing: The Case of South Korea. SSRN Electron J [Internet]. 2020 [cited 2020 Jun 21]; Available from:

https://www.ssrn.com/abstract $=3556346$

70. Bi Q, Wu Y, Mei S, Ye C, Zou X, Zhang Z, et al. Epidemiology and transmission of COVID-19 in 391 cases and 1286 of their close contacts in Shenzhen, China: a retrospective cohort study. Lancet Infect Dis. 2020 Apr;S1473309920302875.

71. El Financiero. Gobierno triplica gasto en salud para atender COVID-19 [Internet]. 2020 [cited 2020 Jun 16]. Available from:

https://www.elfinanciero.com.mx/economia/gobierno-triplica-gasto-en-salud-paraatender-covid-19 